\title{
PENGARUH LINGKUNGAN KERJA, DISIPLIN KERJA, DAN MOTIVASI KERJA TERHADAP KINERJA GURU MADRASAH ALIYAH NEGERI 2 MODEL MEDAN
}

\author{
Sahlan Lubis \\ Magister Manajemen Pendidikan Tinggi, Pascasarjana, \\ Universitas Muhammadiyah Sumatera Utara \\ Medan, Sumatera Utara, Indonesia \\ Sahlanlubis224@yahoo.com
}

\begin{abstract}
Abstrak
Permendiknas RI No.18 Tahun 2007 menjelaskan bahwa ada empat kompetensi sebagai guru profesional yaitu kompetensi pedagogik, profesional, sosial dan kepribadian. Kompetensi yang dimiliki guru tersebut menunjukkan pada kinerja seorang guru. Kondisi dilapangan tentang kinerja guru di MAN 2 Model Medan menunjukkan bahwa terdapat permasalahan yang dihadapi diantaranya yaitu tidak nyamannya guru dengan lingkungan kerjanya yang mengakibatkan beberapa guru mengalami penurunan dalam hal kedisiplinan seperti guru yang datang terlambat dan pengumpulan rencana pembelajaran yang tidak tepat waktu serta kurangnya motivasi para guru untuk meningkatkan kinerjanya. Adapun tujuan dari penelitian ini yaitu untuk mengetahui pengaruh lingkungan kerja, disiplin kerja, dan motivasi kerja terhadap kinerja guru secara parsial dan simultan. Seluruh PNS yang ada di MAN 2 Model Medan sebanyak 68 orang dijadikan sebagai sampel dalam penelitian ini. Setelah dilakukan penyebaran angket, data dianalisis menggunakan regresi linier berganda dan diteruskan dengan menguji R square dan pengujian hipotesis secara parsial dan simultan dengan uji t dan uji $\mathrm{F}$. Hasil penelitian menggunakan uji t (parsial) membuktikan bahwa lingkungan kerja, disiplin kerja dan motivasi kerja masing-masing berpengaruh positif dan signifikan terhadap kinerja guru. Adapun hasil uji F (simultan) menunjukkan bahwasanya lingkungan kerja, disiplin kerja, dan motivasi kerja mempunyai pengaruh yang signifikan dan positif terhadap kinerja guru dengan koefisien korelasi Product Moment $\left(\mathrm{r}_{\mathrm{yx}}\right)$ sebesar 0,617 dan koefisien determinasi $\left(\mathrm{r}_{\mathrm{yx}}{ }^{2}\right)$ sebesar 0,380. Hal ini memiliki arti bahwa apabila Lingkungan Kerja, Disiplin Kerja, dan Motivasi Kerja secara bersama-sama ditingkatkan, maka kinerja guru juga akan meningkat secara signifikan.
\end{abstract}

Kata Kunci_Lingkungan, Disiplin, Motivasi, Kinerja Guru

\section{PENDAHULUAN}

Mencerdaskan kehidupan bangsa yang tercantum dalam pembukaan Undang Undang Dasar 1945, menjadi visi luhur yang tidak bisa diabaikan, khususnya bagi guru yang bertugas sebagai pengajar dan pendidik. Guru merupakan salah satu komponen esensial dalam suatu sistem pendidikan ${ }^{[1]}$. Tugas dan peran seorang guru, telah dijelaskan dalam Undang-Undang Republik Indonesia Nomor 14 Tahun 2005. UndangUndang Republik Indonesia Nomor 14 Tahun 2005 menjelaskan bahwa kedudukan guru sebagai tenaga profesional berfungsi untuk meningkatkan martabat dan peran guru sebagai agen pembelajaran berfungsi untuk meningkatkan mutu pendidikan nasional ${ }^{[2]}$.

Permendiknas RI No. 18 Tahun 2007 menjelaskan bahwa ada empat kompetensi sebagai guru profesional yaitu kompetensi pedagogik, proesional, sosial dan kepribadian, dimana kompetensi yang dimiliki guru tersebut menunjukkan pada kinerja seorang guru. Dalam konteks perubahan saat ini, kinerja inovatif menjadi suatu tuntutan yang makin mendesak untuk dilaksanakan oleh guru dalam melaksanakan peran dan tugasnya sebagai pendidik sehingga dapat melahirkan lulusan yang kreatif dan inovatif yang dapat bersaing di era global saat ini ${ }^{[3]}$. Salah satu sekolah yang ingin terus memperbaiki dan meningkatkan kinerja guru adalah Madrasah Aliyah Negeri 2 Model Medan.

MAN 2 Model Medan merupakan lembaga pendidikaan islam yang berada di jalan Williem Iskandar, No. 7A, Medan yang berkomitmen kuat untuk mengembangkan kualitas madrasah menjadi yang terbaik selaras dengan visi dan misi madrasah yaitu menjadikan madrasah ini menjadi sekolah islam yang layak dan menjadi contoh bagi lembaga pendidikan islam lainnya agar menjadi madrasah yang berintegritas dan berkualitas serta untuk mewujudkan Madrasah Hebat dan Bermartabat. Demi mewujudkan visi dan misi madrasah tersebut, MAN 2 Model Medan harus terus berupaya untuk mengoptimalkan kinerja para gurunya sebagai ujung tombak dari sebuah proses pembelajaran yaitu dengan memperhatikan berbagai aspek yang ada.

Pencapaian kinerja seorang guru secara optimal tidak akan terwujud begitu saja, selain adanya pengembangan kualitas sumber daya manusia yang terarah dan terkoordinasi dengan baik, serta harus didukung juga oleh faktor-faktor yang lain. Faktor tersebut antara lain pengawasan, kondisi lingkungan kerja fisik maupun nonfisik, 
kepemimpinan, kepuasan kerja, kompensasi, teknologi, disiplin kerja, motivasi, pendidikan pelatihan dan sebagainya.

Berdasarkan pengamatan melalui dokumentasi arsip yang dilakukan peneliti dimadrasah tersebut, diperoleh informasi bahwa beberapa guru menunjukkan indikasi kinerja guru belum optimal didasarkan pada hasil supervisi yang dilakukan Kepala Sekolah di Madrasah tersebut. Hal tersebut dapat disebabkan oleh berbagai faktor. Salah satu faktor utama yang mempengaruhi kinerja seorang guru yaitu lingkungan kerja. Lingkungan kerja bagi guru merupakan segala sesuatu yang ada di dalam maupun di luar Madrasah baik lingkungan fisik maupun nonfisik (sosial).

Lingkungan kerja merupakan segala sesuatu yang ada disekitar pekerja dan dapat mempengaruhi dalam menjalankan tugas yang diembankan kepadanya ${ }^{[4]}$. Permasalahan yang ada dalam lingkungan kerja secara fisik, yaitu seperti tidak adanya ruang privasi untuk para guru yang menyebabkan tidak nyamannya para guru didalam ruangan. Sedangkan permasalahan lingkungan non fisik lebih mengarah kepada lingkungan sosial, seperti adanya kelompok/ jarak antar para guru, sehingga memungkinkan para guru hanya berinteraksi dengan individu-individu yang dekat secara fisik maupun emosional. Kondisi ini akan berpengaruh terhadap rendahnya disiplin dan motivasi kerja guru sehingga mereka kurang terdorong untuk bekerja semaksimal mungkin.

Disiplin kerja merupakan perilaku patuh dan taat dalam melaksanakan peraturan kerja yang berupa lisan maupun tulisan dari kelompok maupun organisasi ${ }^{[5]}$. Disiplin kerja adalah salah satu hal yang dapat mempengaruhi kinerja seorang guru. Berdasarkan pengamatan yang dilakukan oleh peneliti, terdapat masalah dalam hal kedisiplinan para guru, seperti keterlambatan pengumpulan perangkat (administrasi) pendidikan dari waktu yang telah ditetapkan dan masih adanya keterlambatan dalam kehadiran para guru.

Motivasi kerja juga merupakan salah satu faktor yang mempengaruhi kinerja seorang guru. Motivasi merupakan kekuatan, baik dari dalam maupun dari luar yang mendorong seseorang untuk mencapai tujuan tertentu yang telah ditetapkan sebelumnya ${ }^{[6]}$. Motivasi kerja yang tinggi dari para guru akan mendorong guru tersebut untuk bekerja semaksimal mungkin dalam melaksanakan tugasnya. Fakta lapangan yang didapatkan peneliti masih terlalu sedikit guru yang memiliki motivasi tinggi dalam bekerja, sehingga membuat kinerja guru secara keseluruhan belum optimal. Hal tersebut disebabkan oleh beberapa hal, seperti kurangnya pelatihan (workshop) yang diadakan oleh pihak madrasah untuk meningkatkan kualitas atau mutu kerja dari para guru. Selain itu, rendahnya motivasi kerja para guru juga disebabkan karena tidak adanya reward (hadiah) dan punishment (hukuman) secara serius bagi para guru.

Melihat berbagai uraian diatas, tentang pentingnya situasi lingkungan kerja, sikap disiplin kerja dan motivasi kerja seorang guru dalam meningkatkan kinerja para guru di MAN 2 Model Medan, maka penulis tertarik untuk melakukan penelitian di madrasah tersebut. Sehingga judul yang diangkat oleh penulis adalah: "Pengaruh Lingkungan Kerja, Disiplin Kerja, dan Motivasi Kerja Terhadap Kinerja Guru Pada Madrasah Aliyah Negeri 2 Model Medan".

Berdasarkan latar belakang masalah, identiikasi masalah dan pembatasan masalah yang telah dikemukakan diatas, maka yang menjadi rumusan masalah dalam penelitian ini, yaitu:

1. Apakah terdapat pengaruh lingkungan kerja terhadap kinerja Guru di MAN 2 Model Medan?

2. Apakah terdapat pengaruh disiplin kerja terhadap kinerja Guru di MAN 2 Model Medan?

3. Apakah terdapat pengaruh motivasi kerja terhadap kinerja Guru di MAN 2 Model Medan?

4. Apakah terdapat pengaruh lingkungan kerja, disiplin kerja, dan motivasi kerja secara bersama-sama terhadap kinerja Guru di MAN 2 Model Medan?

\section{Tujuan Penelitian}

Tujuan yang ingin dicapai pada penelitian ini, yaitu:

1. Untuk mengetahui pengaruh lingkungan kerja terhadap kinerja Guru di MAN 2 Model Medan?

2. Untuk mengetahui pengaruh disiplin kerja terhadap kinerja Guru di MAN 2 Model Medan?

3. Untuk mengetahui pengaruh motivasi kerja terhadap kinerja Guru di MAN 2 Model Medan

4. Untuk mengetahui pengaruh lingkungan kerja, disiplin kerja, dan motivasi kerja secara bersama-sama terhadap kinerja Guru di MAN 2 Model Medan?

\section{Manfaat Penelitian}

Adapun kegunaan/manfaat yang ingin didapatkan dari penelitian ini, yaitu:

1. Bagi Peneliti: Penelitian ini diharapkan dapat menjadi studi perbandingan antara pengetahuan teoritis dengan kondisi nyata di lapangan, khususnya mengenai pengaruh lingkungan kerja, disiplin kerja, dan motivasi kerja terhadap kinerja Guru

2. Bagi Instansi: Hasil penelitian ini diharapkan dapat menjadi sumbangan penting bagi MAN 2 Model Medan dalam 
pengembangan potensi dan kualitas yang dimiliki para Guru madrasah sehingga dapat meningkatkan kinerja para guru di MAN 2 Model Medan

3. Bagi Universitas Muhammadiyah Sumatera Utara: Tesis ini diharapkan dapat menjadi tambahan literatur pengetahuan khususnya mengenai lingkungan kerja, disiplin kerja, dan motivasi kerja terhadap kinerja guru

4. Bagi Pihak Lain: Hasil penelitian ini diharapkan dapat menjadi tambahan rujukan bagi penelitian selanjutnya serta sebagai bahan pertimbangan bagi suatu organisasi/ instansi yang mengalami jenis permasalahan yang sama.

\section{Kajian Pustaka}

\section{Kinerja Guru}

Undang-undang Nomor 14 tahun 2005 tentang Guru dan Dosen, menjelaskan bahwa guru adalah pendidik profesional dengan tugas utama, mendidik, mengajar, membimbing, mengarahkan, melatih, menilai, dan mengevaluasi peserta didik pada pendidikan anak usia dini jalur pendidikan formal, pendidikan dasar, dan pendidikan menengah. guru merupakan profesi/jabatan atau pekerjaan yang memerlukan keahlian khusus sebagai guru ${ }^{[7]}$. Melihat posisi guru yang penting dalam sistem pendidikan nasional, tentu saja kinerja guru menjadi salah satu tolak ukur dalam menentukan baik tidaknya seorang guru dalam melaksanakan tugasnya.

Kinerja merupakan hasil atau keluaran dari suatu proses, dimana kinerja membahas tentang apa yang dikerjakan dan bagaimana cara mengerjakannya ${ }^{[8]}$. Adapun faktor-faktor yang dapat mempengaruhi kinerja seorang guru terdiri dari factor internal dan juga factor eksternal. Faktor internal maupun eksternal, keduanya membawa dampak terhadap kinerja guru, dimana yang dimaksud faktor internal adalah faktor yang datang dari dalam diri guru, contohnya: kemampuan, keterampilan, kepribadian, persepsi, motivasi menjadi guru, pengalaman lapangan, dan latar belakang keluarga, sedangkan faktor eksternal meliputi faktor yang datang dari luar guru, contohnya: gaji, sarana prasarana, lingkungan kerja fisik, kepemimpinan ${ }^{[9]}$.

Peraturan Menteri Negara Pendayagunaan Aparatur Negara dan Reformasi Birokrasi Nomor 16 Tahun 2009 tersebut, menegaskan bahwa Penilaian Kinerja Guru (PKG) adalah penilaian dari tiap butir kegiatan tugas utama guru dalam rangka pembinaan karier, kepangkatan, dan jabatannya. Pada hakikatnya, Penilaian Kinerja Guru (PKG) yaitu untuk meningkatkan kinerja guru melalui pembinaan dan pengawasan yang dilakukan secara terus-menerus dan berkesinambungan $^{[10]}$ Pembinaan dan pengawasan tersebut dapat dilakukan oleh sesama guru, kepala sekolah, dan pengawas sehingga diperoleh guru profesional sebagai basis peningkatan kualitas pendidikan.

Dalam kaitannya dengan kinerja guru, berikut dikemukakan indikator yang menyangkut tugas-tugas guru yang sejalan dengan rumusan kinerja guru seperi pada Permendiknas No. 16 tahun 2007, yaitu (1)Kompetensi Paedagogik, meliputi: Kemampuan pemahaman terhadap peserta didik, Merancang dan melaksanakan pembelajaran, Melaksanakan evaluasi pembelajaran, Mengembangkan potensi peserta didik untuk mengaktualisasi berbagai potensi yang dimilikinya. (2)Kompetensi Profesional, meliputi: Penguasaan materi pembelajaran secara luas dan mendalam, Penguasaan struktur dan metodologi keilmuan. (3)Kompetensi Sosial, meliputi: Mampu berkomunikasi dan bergaul secara efektif baik dengan peserta didik maupun dengan sesama pendidik dan tenaga kependidikan, serta orang tua murid/wali peserta didik dan masyarakat sekitar. (4)Kompetensi Kepribadian, yaitu Memiliki kepribadian mantap dan stabil, dewasa, arif dan memiliki akhlak mulia yang dapat menjadi teladan bagi peserta didik.

\section{Lingkungan Kerja}

Lingkungan kerja dari suatu organisasi merupakan sifat lingkungan kerja atau lingkungan psikologis dalam organisasi yang dirasakan oleh para guru dan dianggap dapat mempengaruhi sikap dan perilaku para guru terhadap pekerjaannya $^{[11]}$. Secara garis besar, jenis lingkungan kerja terbagi menjadi 2 yaitu ${ }^{[8]}$ : (1)Lingkungan Kerja Fisik, dimana Lingkungan kerja fisik adalah semua keadaan berbentuk fisik yang terdapat di sekitar tempat kerja yang dapat mempengaruhi guru baik secara langsung maupun secara tidak langsung. (2)Lingkungan Kerja NonFisik, dimana Lingkungan kerja non fisik adalah semua keadaan yang terjadi yang berkaitan dengan hubungan kerja, baik hubungan dengan atasan maupun hubungan sesama rekan kerja, ataupun hubungan dengan bawahan.

Lingkunga kerja fisik maupun psikis keduanya sama pentingnya dalam suatu, kedua lingkungan kerja ini tidak bisa dipisahkan. Lingkungan kerja terbagi menjadi 4 bagian yang terdiri dari: (1) Hubungan Antara Guru Dengan Pimpinan Organisasi, dimana para guru yang merasakan kepemimpinan yang baik akan termotivasi untuk bekerja dengan sebaik-baiknya. (2) Hubungan Antar Sesama Guru, dengan adanya rekan kerja yang akrab, ramah dan mendukung akan mengarah ke meningkatnya kepuasan kerja, sehingga memotivasi guru untuk lebih giat. (3) Kondisi Kerja, bila kondisi kerja baik (misalnya lingkungan menarik dan bersih), maka guru akan lebih mudah menunaikan tugasnya (4) Fasilitas Kantor, dimana Fasilitas kantor yang dimaksud 
adalah segala sesuatu yang ditempati dan dinikmati oleh guru baik dalam hubungan langsung dengan pekerjaan maupun untuk kelancaran pekerjaan.

\section{Disiplin Kerja}

Disiplin merupakan perilaku patuh dan taat dalam melaksanakan peraturan kerja yang berupa lisan maupun tulisan dari kelompok maupun organisasi ${ }^{[5]}$. Kedisiplinan merupakan fungsi operatif MSDM (Manajemen Sumber Daya Manusia) yang terpenting. Semakin baik disiplin seorang guru pada sebuah instansi, maka akan semakin tinggi pula prestasi kerja yang dicapai ${ }^{[12]}$. Disiplin yang baik mencerminkan besarnya tanggung jawab seseorang terhadap tugas-tugas yang diberikan kepadanya. Hal ini mendorong semangat kerja dan terwujudnya tujuan suatu instansi, guru serta masyarakat pada umumnya.

Ada beberapa faktor yang dapat mempengaruhi disiplin kerja seorang guru, dimana disiplin kerja merupakan suatu sikap dan perilaku. Adapun faktor-faktor yang mempengaruhi disiplin kerja guru, yaitu;(1)Besar Kecilnya Pemberian Kompensasi, (2) Ada Tidaknya Keteladanan Pemimpin Dalam Suatu Instansi, (3)Ada Tidaknya Aturan Pasti Yang Dapat Menjadi Pegangan, (4)Keberanian Pimpinan Dalam Mengambil Tindakan, (5)Ada Tidaknya Pengawasan Pimpinan, (6) Ada Tidaknya Perhatian Kepada Para Guru, (7) Diciptakan kebiasaan-kebiasaan yang mendukung tegaknya disiplin. Selain factor-faktor tersebut, pada dasarnya banyak indikator-indikator yang mempengaruhi tingkat kedisiplinan guru dalam suatu organisasi. Beberapa hal yang menjadi indikator kedisiplinan yaitu; Tanggung Jawab, Prakarsa, Kerjasama, dan Ketaatan ${ }^{[13]}$.

\section{Motivasi Kerja}

Motivasi adalah perubahan energi dalam diri (pribadi) seseorang yang ditandai dengan timbulnya perasaan dan reaksi untuk mencapai tujuan $^{[14]}$. Dalam melakukan suatu pekerjaan, seseorang tak hanya dipengaruhi oleh motivasi ekstrinsik seperti dalam pemenuhan uang semata, namun motivasi intrinsik juga tak dapat terabaikan. Motivasi kerja erat kaitannya dengan perilaku dan prestasi kerja. Semakin tinggi motivasi seseorang dalam melakukan pekerjaan, maka semakin baik perilakunya dalam pelaksanaannya sehingga memberikan prestasi kerja yang lebih baik. Dalam konteks sistem, motivasi mencakup tiga elemen yang berinteraksi dan saling tergantung, yaitu; kebutuhan, dorongan dan insentif.

Pada manusia berlaku faktor motivasi dan faktor pemeliharaan dilingkungan pekerjaanya. Terdapat enam faktor motivasi yaitu; (1) prestasi; (2) pengakuan; (3) kemajuan kenaikan pangkat;
(4) pekerjaan itu sendiri; (5) kemungkinan untuk tumbuh (jenjang karir); (6) tanggung jawab. Sedangkan untuk pemeliharaan terdapat sepuluh faktor yang perlu diperhatikan, yaitu (1) kebijaksanaa; (2) supervisi teknis; (3) hubungan antar manusia dengan atasan ; (4) hubungan manusia dengan pembinanya; (5) hubungan antar manusia dengan bawahannya; (6) gaji dan upah; (7) kestabilan kerja; (8) kehidupan pribadi; (9) kondisi tempat kerja; (10) status ${ }^{[8]}$.

\section{Kerangka Teoritik}

Pengaruh lingkungan kerja, disiplin kerja, dan motivasi kerja terhadap kinerja guru dapat digambarkan dalam kerangka pemikiran sebagai berikut:

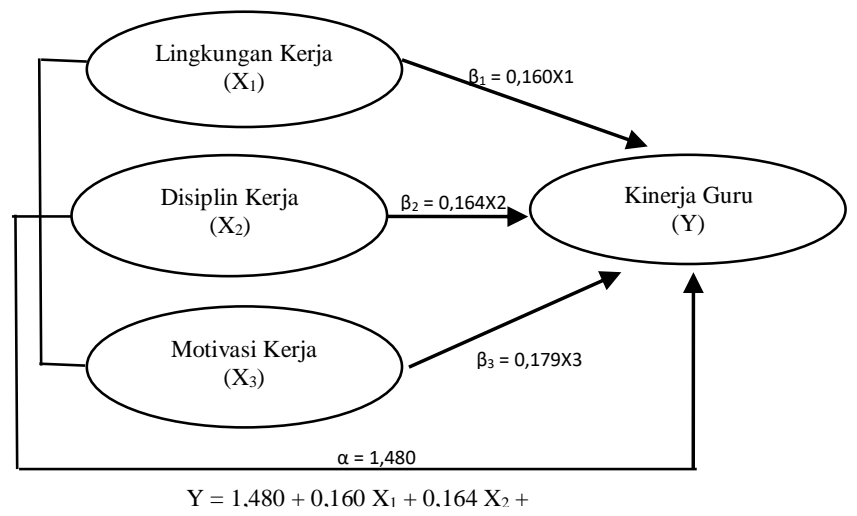

Gambar 2.1. kerangka teoritik

Berdasarkan gambar diatas, tampak bahwa lingkungan kerja, disiplin kerja, dan motivasi kerja seorang guru mempunyai pengaruh yang positif terhadap kinerja para guru. Hal tersebut menyebabkan para pemimpin suatu instansi dalam hal ini kepala MAN 2 Model Medan harus memperhatikan lingkungan kerja, disiplin kerja, dan motivasi kerja para guru, sebab apabila kinerja para guru didukung oleh ketiga hal tersebut dengan baik, maka akan dapat meningkatkan semangat kerja, sehingga dapat menghasilakn kinerja yang optimal.

\section{METODE PENELITIAN}

Metode penelitian yang digunakan dalam penelitian ini adalah metode penelitian kuantitatif dengan membuat angket sebagai instrumen dalam penelitian ini kepada responden (guru) yang akan menjawab pertanyaan-pertanyaan tentang pengaruh lingkungan kerja, disiplin kerja, dan motivasi kerja terhadap kinerja para guru di MAN 2 Model Medan.

Metode penelitian ini digunakan untuk membuktikan hipotesis yang telah disusun terhadap variabel-variabel yang akan diteliti. penelitian ini juga merupakan penelitian yang akan menguji lingkungan kerja, disiplin kerja dan 
motivasi kerja sebagai variabel independen terhadap kinerja guru sebagai variabel dependen.

Adapun pengambilan sampel dalam penelitian ini, dilakukan dengan teknik Pengambilan Sampel Total, dimana seluruh populasi yang ada digunakan sebagai sampel penelitian, sehingga sampel dalam penelitian ini berjumlah 68 orang.

Dalam penelitian kuantitatif, teknik analisis data yang digunakan sudah jelas, dan diarahkan untuk menjawab rumusan masalah atau menguji hipotesis yang telah dirumusan. Dalam rangka menguji hipotesis dalam penelitian ini dilakukan beberapa analisis antara lain yaitu (1) uji klasik atau uji prasyarat, dimana uji prasyarat pada penelitian ini menggunakan uji normalitas dengan uji Kolmogorov-smirnov, uji multikolinearitas, dan uji heterokedastisitas. (2) Uji analisis yaitu menggunakan uji regresi linear Berganda atau uji statistik $\mathrm{F}$ dimana pengujian ini dilakukan untuk menguji pengaruh variabel X1, X2, Dan X3 secara bersama-sama terhadap Y. Selain itu menggunakan uji regresi sederhana atau uji $\mathrm{t}$ dilakukan untuk menguji antar variabel.

\section{HASIL DAN PEMBAHASAN \\ Uji Prasyarat Analisis Data}

Uji yang dilakukan pada penelitian ini adalah untuk mengetahui pengaruh antar variabel yang diuji menggunakan uji regresi linear. Sebelum melakukan uji analisis, terlebih dahulu dilakukan uji prasyarat. Uji prayarat dilakukan untuk mengetahui apakah analisis data untuk pengujian hipotesis dapat dilanjutkan atau tidak. Adapun uji prasyarat yang digunakan yaitu: (1) Uji normalitas distribusi, pengujian normalitas dilakukan untuk mengetahui normal atau tidaknya distribusi data. Adapun hasil uji normalitas distribusi ini bahwa variabel lingkungan kerja memiliki nilai sig $=0,081>0,05$, disiplin kerja $\operatorname{sig}=0,072>0,05$, motivasi kerja sig $=0,073>$ 0,05 dan kinerja guru sig $=0,051>0,05$ karena angka signifikansi dari masing-masing variabel tesebut > dari 0,05 maka berdasarkan criteria pengujian normalitas menunjukkan bahwa keempat variabel tersebut berdistribusi normal. (2) Uji Multikolinieritas, uji ini dilakukan untuk menguji model regresi apakah ada korelasi antara variabel bebas. Jika variabel bebas saling berkorelasi, maka variabel-variabelnya tidak ortogonal. Adapun hasil uji multikolinieritas ini menunjukkan bahwa nilai VIF dan Tolerance mengindikasikan tidak terdapat multikolonieritas yang serius. Dimana VIF untuk lingkungan kerja sebesar 1,047, disiplin kerja sebesar 1,256, dan motivasi kerja sebesar 1,306, sehingga tidak ada nilai VIF yang melebihi 10. Selain itu nilai Tolerance tidak ada yang kurang dari 0,10 , dimana nilai Tolerance dari lingkungan kerja=
0,955 , disiplin kerja $=0,796$, dan motivasi kerja $=$ 0,766. (3) Uji Heterokedastisitas, Uji ini digunakan untuk menguji ada atau tidaknya heterokedastisitas dengan uji Scatterplot dan lebih diperjelas menggunakan uji glejser. Adapun hasil uji heterokedastisitas berdasarkan grafik Scatterplot dapat disimpulkan bahwa tidak terjadi masalah heterokedastisitas, hingga model regresi yang baik dan ideal dapat terpenuhi. Hal tersebut diperkuat dengan hasil uji glejser yang didapat, dimana nilai signifikansi dari seluruh variabel diatas 0,05 , yaitu lingkungan kerja $=0,779$, disiplin kerja $=0,666$, dan motivasi kerja $=0,120$.

Berdasarkan keseluruhan hasil uji prasyarat analasis data yang didapat maka disimpulkan bahwa data angket yang telah didapat layak untuk dilakukan pengujian hipotesis menggunakan uji lainnya demi menjawab hiopotesis yang ada.

\section{Pembahasan Hipotesis Penelitian}

Untuk menunjukkan seberapa jauh pengaruh satu variabel independen (Lingkungan Kerja, Disiplin Kerja dan Motivasi) secara individual dalam menerangkan variabel dependen (kinerja guru). Dasar Pengambilan keputusan pada uji $\mathrm{t}$ dapat dilihat dari kolom signifikansi hasil output SPSS. Apabila nilai sig. $<\alpha(0,05)$, maka $\mathrm{H}_{0}$ ditolak dan $\mathrm{H}_{\mathrm{a}}$ diterima, sehingga variabel independen berpengaruh signifikan terhadap variabel dependen. Sedangkan apabila nilai sig. > a $(0,05)$ maka $\mathrm{H}_{0}$ diterima dan $\mathrm{H}_{\mathrm{a}}$ ditolak, sehingga variabel independen tidak berpengaruh signifikan terhadap variabel dependen.

\section{Pengaruh variabel Lingkungan Kerja (X1) terhadap Kinerja Guru (Y).}

Adapun hasil analisis data pada pengaruh lingkungan kerja (X1) terhadap kinerja guru (Y) di MAN 2 Model Medan tertera pada tabel berikut:

Tabel 3.1 Hasil Uji Regresi X1 Terhadap Y

\begin{tabular}{|c|c|c|c|c|c|}
\hline \multirow[b]{2}{*}{ Model } & \multicolumn{2}{|c|}{$\begin{array}{l}\text { Unstandardi } \\
\text { zed } \\
\text { Coefficients }\end{array}$} & $\begin{array}{l}\text { Standardi } \\
\text { zed } \\
\text { Coefficie } \\
\text { nts }\end{array}$ & \multirow[b]{2}{*}{$\mathrm{T}$} & \multirow[b]{2}{*}{ Sig } \\
\hline & B & $\begin{array}{l}\text { Std. } \\
\text { Error }\end{array}$ & Beta & & \\
\hline (constan & 2,62 & & & 10,05 & , 00 \\
\hline t) & 0 & ,261 & & 5 & 0 \\
\hline $\begin{array}{c}\text { Lingkun } \\
\text { gan } \\
\text { Kerja }\end{array}$ & ,210 &, 065 & ,368 & 3,217 & $\begin{array}{r}, 00 \\
2\end{array}$ \\
\hline
\end{tabular}

\section{a. Dependent Variable: Kinerja Guru}

Dari hasil pengolahan statistik tersebut didapatkan persamaan regresi $\mathrm{Y}=2,620+$ $0,210 X 1$. Hal tersebut menunjukkan bahwa lingkungan kerja berpengaruh positif dan signifikan terhadap kinerja guru. Sementara itu, untuk melihat seberapa besar hubungan pengaruh 
Lingkungan Kerja terhadap Kinerja Guru dapat dilihat pada tabel berikut:

Tabel 3.2 Hasil Uji Pengaruh X1 Terhadap Y

\begin{tabular}{|l|c|c|r|r|}
\hline Model & $\mathrm{R}$ & $\begin{array}{c}\mathrm{R} \\
\text { Squ } \\
\text { are }\end{array}$ & $\begin{array}{c}\text { Adjusted } \\
\text { R Aquare }\end{array}$ & $\begin{array}{c}\text { Std. Error of } \\
\text { the Estimate }\end{array}$ \\
\hline 1 &, 36 &, 136 &, 122 &, 21702 \\
\hline
\end{tabular}

a. Predictors: (Constant), Lingkungan Kerja

Berdasarkan tabel tersebut, dapat diketahui besarnya pengaruh Lingkungan Kerja terhadap Kinerja Guru yaitu sebesar 13,6\%, sedangkan $86,4 \%$ dipengaruhi oleh faktor lain. Hal tersebut menjelaskan bahwa persamaan regresi antara Lingkungan Kerja (X1) terhadap Kinerja Guru (Y) adalah linear dan signifikan sebesar 13,6\%.

Uji hipotesis pada variabel lingkungan kera ini membuktikan bahwa lingkungan kerja berpengaruh positif dan signifikan terhadap kinerja guru, dengan nilai koefisien positif sebesar 0,210 dan nilai sig. sebesar 0,002 yang berarti dibawah 0,05. Adanya angka positif dan signifikan tersebut dapat diidentifikasi jika semakin baik lingkungan kerja yang disediakaan untuk para guru maka akan berpengaruh semakin meningkatnya kinerja guru di MAN 2 Model Medan.

Hasil penelitian ini sejalan dengan yang dilakukan oleh Rediana (2012), Prihantoro (2012), dan Eliyanto (2018) yang menyatakan bahwa lingkungan kerja berpengaruh positif dan signifikan terhadap kinerja.

\section{Pengaruh variabel Disiplin Kerja terhadap Kinerja Guru.}

Adapun hasil analisis data pada pengaruh disiplin kerja (X2) terhadap kinerja guru (Y) di MAN 2 Model Medan dapat dilihat pada tabel berikut:

Tabel 3.3 Hasil Uji Regresi X2 Terhadap Y

\begin{tabular}{|c|c|c|c|c|c|}
\hline \multirow[b]{2}{*}{$\begin{array}{c}\text { Mod } \\
\text { el }\end{array}$} & \multicolumn{2}{|c|}{$\begin{array}{l}\text { Unstandardi } \\
\text { zed } \\
\text { Coefficients }\end{array}$} & \multirow{2}{*}{$\begin{array}{l}\text { Standar } \\
\text { dized } \\
\text { Coeffic } \\
\text { ients } \\
\text { Beta }\end{array}$} & & \multirow[b]{2}{*}{ Sig } \\
\hline & B & $\begin{array}{l}\text { Std. } \\
\text { Error }\end{array}$ & & & \\
\hline (cons & 2,44 & & & & ,00 \\
\hline $\tan t)$ & 5 & ,250 & & 9,780 & 0 \\
\hline Diaip & & & & & 00 \\
\hline $\begin{array}{c}\operatorname{lin} \\
\text { Kerja }\end{array}$ & ,255 & ,063 & ,446 & 4,054 & $\begin{array}{r}, 00 \\
0\end{array}$ \\
\hline
\end{tabular}

a. Dependent Variable: Kinerja Guru

Berdasarkan tabel diatas diperoleh persamaan regresi antara variabel Disiplin Kerja (X2) terhadap Kinerja Guru (Y), yaitu Y $=2,445+$ $0,225 \mathrm{X} 2$. Hal tersebut menjelaskan bahwa adanya pengaruh yang positif antara variabel $\mathrm{X}_{2}$ terhadap $\mathrm{Y}$ dengan nilai koefisien positif $(0,225)$ dan nilai signifikan (0,000), dimana nilai ini dibawah 0,05. Maka hipotesis yang menyatakan bahwa faktor Disiplin Kerja berpengaruh positif terhadap Kinerja Guru MAN 2 Model Medan diterima.

Sementara itu, untuk melihat besarnya hubungan pengaruh Disiplin Kerja terhadap Kinerja Guru dapat dilihat pada tabel berikut:

Tabel 3.4 Hasil Uji Hubungan X2 Terhadap Y

\begin{tabular}{|c|c|r|r|r|}
\hline $\begin{array}{c}\text { Mode } \\
1\end{array}$ & $\mathrm{R}$ & $\begin{array}{c}\mathrm{R} \\
\text { Square }\end{array}$ & $\begin{array}{c}\text { Adjusted } \\
\text { R Aquare }\end{array}$ & $\begin{array}{r}\text { Std. Error of } \\
\text { the Estimate }\end{array}$ \\
\hline 1 &, $446^{\mathrm{a}}$ &, 199 &, 187 &, 20885 \\
\hline
\end{tabular}

a. Predictors: (Constant), Disiplin Kerja

Berdasarkan tabel tersebut, dapat diketahui besarnya pengaruh Disiplin Kerja terhadap Kinerja Guru yaitu sebesar 19,9\%, sedangkan $80,1 \%$ dipengaruhi oleh faktor lain. Hal tersebut menjelaskan bahwa persamaan regresi antara Disiplin Kerja (X1) terhadap Kinerja Guru (Y) adalah linear dan signifikan sebesar 19,9\%.

Uji hipotesis membuktikan bahwa disiplin kerja berpengaruh positif dan signifikan terhadap kinerja guru, dengan nilai koefisien sebesar 0,255 dan nilai sig. sebesar 0,000 yang berarti dibawah 0,05 . Adanya angka positif dan signifikan tersebut dapat diidentifikasikan jika semakin tinggi disiplin kerja maka akan semakin berpengaruh terhadap kinerja para guru di MAN 2 Model Medan.

Hasil dari penelitian ini sejalan dengan yang dilakukan oleh Hadiati (2018), Husna (2017), dan Arianto (2013) yang menyatakan bahwa disiplin kerja berpengaruh positif dan signifikan terhadap kinerja guru di MAN 2 Model Medan.

\section{Pengaruh variabel Motivasi Kerja terhadap Kinerja Guru.}

Adapun hasil analisis data pada pengaruh motivasi kerja (X3) terhadap kinerja guru (Y) di MAN 2 Model Medan dapat dilihat pada tabel berikut:

Tabel 3.5 Hasil Uji Regresi X3 Terhadap Y

\begin{tabular}{|c|c|c|c|c|c|}
\hline \multirow[b]{2}{*}{ Model } & \multicolumn{2}{|c|}{$\begin{array}{l}\text { Unstandardi } \\
\text { zed } \\
\text { Coefficients }\end{array}$} & \multirow{2}{*}{$\begin{array}{c}\begin{array}{c}\text { Standardi } \\
\text { zed } \\
\text { Coefficie } \\
\text { nts }\end{array} \\
\text { Beta }\end{array}$} & \multirow[b]{2}{*}{1} & \multirow[b]{2}{*}{ Sig } \\
\hline & B & $\begin{array}{l}\text { Std. } \\
\text { Error }\end{array}$ & & & \\
\hline (constan & 2,33 & & & & ,00 \\
\hline t) & 1 & ,246 & & 9,486 & 0 \\
\hline $\begin{array}{c}\text { Motivasi } \\
\text { Kerja }\end{array}$ & ,290 & ,063 & ,492 & 4,590 & $\begin{array}{r}, 00 \\
0\end{array}$ \\
\hline
\end{tabular}

a. Dependent Variable: Kinerja Guru

Berdasarkan tabel diatas diperoleh persamaan regresi antara variabel Motivasi Kerja (X3) terhadap Kinerja Guru (Y), yaitu Y = 2,331 + $0,290 X 3$. Hal tersebut menjelaskan bahwa adanya 
pengaruh yang positif antara variabel $\mathrm{X}_{3}$ terhadap $Y$ dengan nilai koefisien positif $(0,290)$ dan nilai signifikan $(0,000)$, dimana nilai ini dibawah 0,05 . Maka hipotesis yang menyatakan bahwa faktor Disiplin Kerja berpengaruh positif terhadap Kinerja Guru MAN 2 Model Medan diterima.

Sementara itu, untuk melihat besarnya hubungan pengaruh Motivasi Kerja terhadap Kinerja Guru dapat dilihat pada tabel berikut:

Tabel 3.6 Hasil Uji Hubungan X3 Terhadap Y

\begin{tabular}{|l|r|r|r|r|}
\hline $\begin{array}{c}\text { M } \\
\text { od } \\
\text { el }\end{array}$ & $\mathrm{R}$ & $\begin{array}{c}\mathrm{R} \\
\text { Square }\end{array}$ & $\begin{array}{c}\text { Adjusted } \\
\text { R Aquare }\end{array}$ & $\begin{array}{c}\text { Std. Error of } \\
\text { the Estimate }\end{array}$ \\
\hline 1 &, $492^{\mathrm{a}}$ &, 242 &, 230 &, 20321 \\
\hline
\end{tabular}

a. Predictors: (Constant), Motivasi Kerja

Berdasarkan tabel tersebut, dapat diketahui besarnya pengaruh Motivasi Kerja terhadap Kinerja Guru yaitu sebesar 24,2\%, sedangkan $75,8 \%$ dipengaruhi oleh faktor lain. Hal tersebut menjelaskan bahwa persamaan regresi antara Disiplin Kerja (X1) terhadap Kinerja Guru (Y) adalah linear dan signifikan sebesar 24,2\%.

Uji hipotesis membuktikan bahwa motivasi kerja berpengaruh positif dan signifikan terhadap kinerja guru, dengan nilai koefisien positif sebesar 0,290 dan nilai sig. sebesar 0,000 yang berarti dibawah 0,05. Adanya angka positif dan signifikan tersebut dapat diidentifikasi jika semakin tinggi motivasi kerja yang dimiliki para guru maka akan berpengaruh semakin meningkatnya kinerja guru di MAN 2 Model Medan.

Hasil penelitian ini sejalan dengan yang dilakukan oleh Eros (2014), Eliyanto (2018) dan Mulyapradana (2017), yang menyatakan bahwa motivasi kerja berpengaruh positif dan signifikan terhadap kinerja.

Pengaruh Lingkungan Kerja, Disiplin Kerja, dan Motivasi Kerja Secara Bersama-sama Terhadap Kinerja Guru

Uji Simultan atau uji $F$ dilakukan untuk mengetahui penmgaruh lingkungan kerja, disiplin kerja, dan motivasi kerja secara bersama-sama terhadap kinerja guru di MAN 2 Model Medan. Uji dapat dilakukan dengan cara melihat kolom signifikansi hasil output SPSS (tabel anova). Model dapat dikatakan signifikan atau layak jika kolom signifikansi $<$ dari $\alpha(0,05)$, sehingga $\mathrm{H}_{0}$ ditolak $\mathrm{H}_{\mathrm{a}}$ diterima. Begitu sebaliknya model dapat dikatakan tidak signifikan atau tidak layak jika kolom signifikansi $>$ dari $\alpha(0,05)$ sehingga $\mathrm{H}_{0}$ diterima dan $\mathrm{H}_{\mathrm{a}}$ ditolak. Hasil dari pengujian SPSS dapat dilihat pada tabel berikut ini:
Tabel 3.7 Hasil Uji Simultan

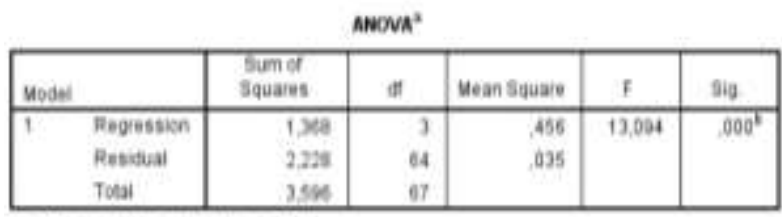

a Dependint Variaia kinerpa Gums

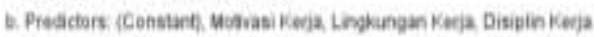

Dari hasil tabel diatas menunjukkan hasil sig. 0,000 yaitu $<0,05$ dapat dikatakan bahwa model regresi yang diestimasi layak dan dapat digunakan untuk menjelaskan bahwa terdapat pengaruh lingkungan kerja, disiplin kerja dan motivasi kerja secara simultan terhadap kinerja guru MAN 2 Model Medan.

Selain itu, Regresi linier berganda juga digunakan untuk mengetahui besarnya pengaruh Lingkungan kerja, Disiplin Kerja dan Motivasi Kerja terhadap kinerja guru MAN 2 Model Medan. Melalui perhitungan SPSS, formulasi dari analisis regresi dapat dilihat pada tabel berikut:

Tabel 3.8 Hasil Uji Regresi Linier Berganda

\begin{tabular}{|c|c|c|c|c|c|}
\hline \multirow[b]{2}{*}{ Model } & \multicolumn{2}{|c|}{$\begin{array}{l}\text { Unstandard } \\
\text { ized } \\
\text { Coefficient } \\
\text { s }\end{array}$} & \multirow{2}{*}{\begin{tabular}{|c|c}
$\begin{array}{c}\text { Standardi } \\
\text { zed } \\
\text { Coefficie } \\
\text { nts }\end{array}$ \\
Beta \\
\end{tabular}} & \multirow[b]{2}{*}{$\mathrm{t}$} & \multirow[b]{2}{*}{ Sig. } \\
\hline & B & $\begin{array}{c}\text { Std. } \\
\text { Error }\end{array}$ & & & \\
\hline (constant) & $\begin{array}{r}1,48 \\
0\end{array}$ & $\begin{array}{r}, 32 \\
0\end{array}$ & & $\begin{array}{r}4,62 \\
8\end{array}$ &, 000 \\
\hline $\begin{array}{l}\text { Lingkunga } \\
\mathrm{n} \text { Kerja }\end{array}$ &, 160 & $\begin{array}{r}, 05 \\
7\end{array}$ & ,280 & $\begin{array}{r}2,78 \\
4\end{array}$ & ,007 \\
\hline $\begin{array}{l}\text { Disiplin } \\
\text { Keria }\end{array}$ & , 164 & $\begin{array}{r}, 06 \\
3\end{array}$ & 287 & $\begin{array}{r}2,59 \\
9\end{array}$ & 012 \\
\hline $\begin{array}{l}\text { Motivasi } \\
\text { Kerja }\end{array}$ & 179 & $\begin{array}{r}, 06 \\
6\end{array}$ & ,303 & $\begin{array}{r}2,69 \\
7\end{array}$ & 009 \\
\hline
\end{tabular}

a. Dependent Variable:

Berdasarkan hasil pengolahan data dengan analisis regresi linier berganda diatas, dihasilkan bentuk regresi linier berganda antara ketiga variabel tersebut yang dinyatakan oleh persamaan rumus regresi linier berganda sebagai berikut:

$$
\begin{aligned}
& \mathrm{Y}=\alpha+\beta_{1} \mathrm{X}_{1}+\beta_{2} \mathrm{X}_{2}+\beta_{3} \mathrm{X}_{3}+e \\
& \mathrm{Y}=1,480+0,160 \mathrm{X}_{1}+0,164 \mathrm{X}_{2}+0,179 \mathrm{X}_{3}+
\end{aligned}
$$
$e$

Persamaan regresi ini memiliki arti bahwa apabila Lingkungan Kerja, Disiplin Kerja, dan Motivasi Kerja secara bersama-sama ditingkatkan, maka kinerja guru juga akan meningkat secara signifikan.

Selanjutnya untuk mengukur seberapa jauh kemampuan model dalam menerangkan variasi variabel dependen digunakan penghitungan koefisien determinasi $\left(\mathrm{R}^{2}\right)$. Adapun hasil Koefisien Determinasi penelitian ini dapat dilihat pada tabel berikut: 
Tabel 3.9 Hasil Uji Koefisien Determinan Model Summary

\begin{tabular}{l|c|c|c|r}
\hline Model & R & R Square & $\begin{array}{c}\text { Adjusted R } \\
\text { Square }\end{array}$ & $\begin{array}{c}\text { Std. Error i } \\
\text { the Estima }\end{array}$ \\
\hline 1 &, $617^{\text {a }}$ &, 380 &, 351 &, 186 \\
\hline
\end{tabular}
a. Predictors: (Constant), Motivasi Kerja, Lingkungan Kerja,
Disiplin Kerja

Berdasarkan hasil analisis korelasi terhadap pasangan data dari ketiga variabel tersebut dihasilkan koefisien korelasi Product Moment sebesar $\mathrm{r}_{\mathrm{yx}}=0,617$ dan koefisien determinasi $\left(\mathrm{r}_{\mathrm{yx}}{ }^{2}\right)$ sebesar 0,380. Hal ini berarti bahwa Lingkungan Kerja, Disiplin Kerja, dan Motivasi Kerja secara bersama-sama memberikan pengaruh terhadap kinerja guru sebesar 38\%. Lingkungan Kerja, Disiplin Kerja, dan Motivasi Kerja secara bersama-sama dalam meningkatkan kinerja guru cukup besar. Dimana, ketiga variabel tersebut memberikan kontribusi sebesar 38\% terhadap kinerja guru sedangkan $62 \%$ dipengaruhi oleh faktor lain yang tidak dibahas dalam penelitian ini.

Temuan tersebut mendukung pendapat dan teori yang telah dikemukakan pada kajian pustaka, bahwa banyak faktor yang mempengaruhi kinerja guru, dimana faktor-faktor yang dapat mempengaruhi kinerja guru antara lain yaitu; (1)Sikap mental (motivasi kerja, disiplin, etika atau budaya kerja), (2)Pendidikan, (3)Ketrampilan, (4)Manajemen kepemimpinan, (5)Tingkat penghasilan, (6)Gaji dan kesehatan, (7)Jaminan sosial atau kesejahteraan, (8)Iklim kerja, (9)Sarana prasarana yang memadai, (10)Teknologi, (11)Kesempatan untuk berprestasi $^{[8]}$.

Oleh karena itu, peningkatan yang positif terjadi pada Lingkungan Kerja, Disiplin Kerja, dan Motivasi Kerja secara bersama-sama juga akan mendukung terhadap peningkatan kinerja guru. Adanya pengaruh yang signifikan dan regresi linier serta korelasi yang positif antara Lingkungan Kerja, Disiplin Kerja, dan Motivasi Kerja secara bersama-sama terhadap kinerja guru membuktikan bahwa teori yang menyatakan Lingkungan Kerja, Disiplin Kerja, dan Motivasi Kerja secara bersama- sama akan menentukan kondisi guru dan diduga dapat meningkatkan kinerjanya dalam kepustakaan sejalan dengan kerangka berpikir yang diajukan. Dengan demikian, lewat penelitian ini terbukti bahwa Lingkungan Kerja, Disiplin Kerja, dan Motivasi Kerja secara bersama-sama merupakan salah satu faktor penentu bagi kinerja guru, disamping faktor-faktor lainnya.

\section{KESIMPULAN DAN SARAN Kesimpulan}

Berdasarkan rumusan masalah, tujuan penelitian, hipotesis penelitian, analisis data dan pembahasan hasil penelitian, maka dapat disimpulkan sebagai berikut:

1. Terdapat pengaruh yang signifikan antara lingkungan kerja terhadap kinerja guru di MAN 2 Model Medan, yang mengandung arti bahwa semakin baik lingkungan kerja seorang guru maka semakin baik pula kinerjanya, sebaliknya semakin buruk lingkungan kerja seorang guru maka kinerja guru tersebut juga akan semakin buruk

2. Disiplin kerja seorang guru berpengaruh berpengaruh secara signifikan terhadap kinerja guru di MA N 2 Model Medan, dimana hal ini bermakna semakin tinggi disipln kerja seorang guru maka kinerja guru juga akan semakin baik, namun sebaliknya semakin rendah disiplin kerja seorang guru maka kinerja guru tersebut akan semakin rendah pula

3. Terdapat pengaruh yang signifikan antara motivasi kerja terhadap kinerja seorang guru yang bermakna bahwa semakin besar motivasi kerja seorang guru maka semakin baik pula kinerjanya, sebaliknya semakin rendah motivasi kerja seorang guru maka kinerja guru tersebut juga akan semakin buruk

4. Ada pengaruh yang signifikan secara simultan antara lingkungan kerja, disiplin kerja,dan motivasi kerja terhadap kinerja guru di MAN 2 Model Medan, dimana hal ini berarti semakin baik lingkungan kerja, semakin tinggi disiplin kerja dan semakin besar motivasi kerja seorang guru secara bersama-sama maka kinerja guru tersebut akan semakin baik pula, namun sebaliknya semakin buruk lingkungan kerja, semakin rendah disiplin kerja dan semakin kecil motivasi kerja seorang guru secara bersamasama maka kinerja guru tersebut juga akan semakin buruk

\section{Saran}

Berdasarkan kesimpulan dan implikasi penelitian yang telah diuraikan diatas, maka diajukan beberapa saran sebagai berikut:

1. Saran Untuk Guru

Demi terwujudnya kinerja guru yang maksimal, maka disarankan kepada para guru agar dapat memperhatikan beberapa hal berikut:

a. Meningkatkan sikap disiplin dan motivasi kerja yang dimiliknya, dimana meningkatnya sikap disiplin dan motivasi kerja tidak hanya dipengaruhi oleh faktor luar saja, tetapi yang lebih penting adalah yang berasal dari diri sendiri. 
b. Memberikan inovasi sesuai dengan perkembangan tekhnologi dalam sistem pembelajaran didalam kelas.

c. Mengatur waktu agar dapat mengumpulkan perangkat (administrasi) pendidikan sesuai dengan waktu yang telah ditetapkan

2. Saran Untuk Kepala Sekolah

Demi terwujudnya visi misi sekolah yang optimal maka kinerja maksimal dari para guru sangat lah menentukan keberhasilan suatu sekolah. Oleh karena itu, maka terdapat beberapa saran yang dapat menjadi perhatian bagi para kepala sekolah/Madrasah, yaitu sebagai berikut:

a. Melakukan peningkatan kualitas lingkungan kerja, agar lingkungan kerja para guru menjadi nyaman dan kondusif sehingga dapat memberikan pengaruh baik terhadap kinerja para guru, seperti menyediakan ruang privasi untuk para guru didalam ruangan.

b. Mengintensifkan pembinaan kepada para guru terkait dengan kinerja guru seperti melaksakan seminar atau workshop terkait kurikulum ataupun metode pengajaraan dikelas

c. Memberi penghargaan kepada guru atas prestasi kerja yang diperoleh guru untuk meningkatkan motivasi kerja para guru.

d. Memberikan sanksi yang tegas kepada para guru yang melanggar aturan yang telah ditetapkan pihak sekolah

\section{DAFTAR PUSTAKA}

[1] Pramudyo, A, 2010, Analisis Faktor-Faktor yang Mempengaruhi Kinerja Dosen Negeri Dipekerjakan pada Kopertis Wilayah V Yogyakarta, Jurnal Managemen Sumberdaya Manusia, Vol 1(1).

[2] Departemen Pedidikan Dan Kebudayaan. 1998, Panduan Manajemen Madrasah. Departemen Pendidikan Dan Kebudayaan.

[3] Suharsaputra, U., 2012, Metode Penelitian: Kuantitatif, Kualitatif dan Tindakan, PT. Refika Aditama, Bandung.

[4] Nitisemito, Alex, S., 2013, Manajemen Personalia, Ghalia Indonesia, Jakarta.

[5] Husin, 2000, Aplikasi Statistik Praktis Dengan SPSS 9, PT. Elex Media, Jakarta

[6] Uno, Hamzah B, 2008, Profesi Kependidikan: Problema, Solusi, dan Reformasi Pendidikan di Indonesia, Bumi Aksara, Jakarta

[7] Usman, M.U., 2013, Menjadi Guru Profesional., Rosdakarya, Bandung

[8] Sedarmayanti, 2001, Sumber Daya Manusia Dan Produktifitas Kerja, Mandar Maju, Bandung
[9] Arifin, Z., 2012, Penelitian Pendidikan Metode dan Paradigma Baru, Remaja Rosda Karya, Bandung.

[10] Mulyasa, E., 2004, Menjadi Guru Profesional, PT. Remaja Rosdakarya, Bandung

[11] Agustini, F., 2011, Manajemen Sumber Daya Manusia Lanjutan: Pendekatan Pengelolaan Sumberdaya Manusia Sebagai Kompetensi Inti Dalam Suatu Organisasi, Madenatera, Medan.

[12] Rivai, V., 2011, Manajemen Sumber Daya Manusia Untuk Perusahaan, Raja Grafindo, Jakarta

[13] Supomo Dan Nurhayati., 2018, Manajemen Sumber Daya Manusia, YramaWidya, Bandung

[14] Hamalik, O., 2011, Proses Belajar Mengajar, Bumi Aksara, Jakarta 